\title{
Quality of Raw Water from Ghana's Reservoirs: A Case of Weija
} Reservoir

\author{
Lord Ebow Sampson* Oscar Opoku Agyemang \\ Department of Geography and Regional Planning, University of Cape Coast, PMB, Cape Coast, Ghana
}

\begin{abstract}
The increase in population within the Densu River Basin (DRB) from 450,000 in 1984 to 947,000 in 2000 shows an average yearly growth rate of $3.26 \%$. This therefore has resulted in the increase of anthropogenic activities which have caused contamination with regard to the quality of raw water from the Weija reservoir. Using descriptive study design, the study aimed at analyzing the trends in water quality parameters and also finding some of the existing relationships between these parameters over a 14-year period. The study used sixteen (16) water quality parameters and it was revealed that most of the water quality parameters' recordings fell within the WHO guidelines during the 14-year period. Water from the Weija Lake can be termed to have been of high quality putting into consideration phosphorus, nitrate, ammonia, magnesium, calcium, total hardness, fluoride, iron and sulphate since they fell within WHO guidelines: this effect gives a signal of resource sustainability by the population within the catchment. On the other hand, the water can be termed to have been of less quality over the 14 years by considering parameters such as turbidity, colour, $\mathrm{pH}$, temperature, suspended solids and total solids since their recordings were often above WHO guidelines. In view of this, it is recommended that stakeholders of DRB such as the Densu River Authority (DRA), the Ghana Water Commission (GWC), the Weija Head Works (WHW) and the District Assemblies should ensure that sustainability of quality of water from the Weija reservoir is achieved through clean integration of social, environmental and economic developments as emphasized in the definition of sustainability given by the Bruntland commission.
\end{abstract}

Keywords: Raw water, Quality, Reservoirs, weija

DOI: $10.7176 / \mathrm{JEES} / 10-5-01$

Publication date:May $31^{\text {st }} 2020$

\section{Introduction}

Water is an important natural endowment available to mankind and of high significance to food production, human livelihoods, and the preservation of life and natural surroundings. However, the influences of anthropogenic factors have affected the quality of water resources in many regions of the world (Piao, Ciais, \& Huang, 2010). Worldwide projections have revealed that water consumption for most users will rise by at least 50 percent by 2025 compared to its level of usage in 1995 (Rosegrant, 2002). Reservoirs that are meant to supply water (including Weija Reservoir) to the populace of Ghana in many sections of the country ensure that sustainable and reliable source of raw water is treated and provided to major towns and cities throughout the year.

The quality of water worldwide is reducing mainly as a result of human actions such as quick growth in urbanization, increase in population growth and the release of new chemicals and new pathogens from invasive species and industries (Piao et al., 2010). In recent times, Ghana has experienced a continuous encroachment on protected areas along water bodies and this has been a major problem for the country. According to Anon (2002), the increase in human population within the Densu River Basin (DRB) from 450,000 in the year 1984 to 947,000 in 2000 shows a yearly growth rate of $3.26 \%$. This has resulted in so many environmental challenges, principal among which are deforestation, pollution and land encroachment, confronting the river basin. Due to the poor waste disposal practices of communities within the DRB, the river has been turned into a refuse receptacle as it was indicated by Asante, Quarcoopome and Amevenku (2005), with people pouring anything unwanted into it. As a matter of fact, the pollution occurs along the entire course of the river, until everything eventually assembles in the reservoir (Anon, 2000). The raw water acquired directly from the reservoir to satisfy the needs of the fast growing populations in urban areas changes in quality in accordance with the level of pollution of the River Densu (Department for International Development [DFID], 1999). This situation, to a large extent, has been attributed to anthropogenic activities (Asante et al., 2005). Such activities include municipal and industrial liquid and solid wastes, indiscriminate dumping of domestic wastes, improper land use, environmental degradation and poor agricultural practices along the basin of the river and also within and around the reservoir's catchment.

The quest to improve the quality of water in the Weija reservoir had resulted in the conduct of many studies including water quality of the Weija reservoir after 28 years of impoundment ( Asante, Quarcoopome, \& Amevenku, 2005), comparison of the Weija, Brimsu and Inchaban reservoirs in Ghana (Bosque-Hamilton, NanaAmankwaa \& Karikari, 2004) and a study by Ansa-Asare and Asante (1998) compared the Weija and Kpong reservoirs in Ghana with reference to nutrient status by determining the seasonal indices and interannual changes over a 5- year period from 1993-1997.

Results from the study by Asante et al. (2005) were that values of $\mathrm{pH}$ levels were within the recommended 
range of $6.5-8.5$. Iron levels exceeded the WHO guideline value of $0.30 \mathrm{mg} / \mathrm{l}$ by $90 \%, 80 \%$ and $80 \%$ for the Weija intake, Machigani and Galilea respectively. Generally, the researchers concluded that phosphate, nitrate, sulphate, iron, manganese and Bod levels were reasonably high and this signifies nutrient enrichment, organic contamination and gradual deterioration of the quality of water found in the Weija reservoir.

Ansa-Asare and Asante (1998) revealed that levels of nutrient and seasonal distribution of nutrients were higher in the Weija reservoir than the Kpong reservoir. Seasonal variation demonstrated higher recordings of nitrates in the rainy season at Weija than at Kpong. The months of March and May showed a unique pattern in the monthly trend of nitrates; this is the main ploughing seasons for farming in the Weija catchment area when most fertilizer is applied. In a general view, there were no trends in nutrient levels over the 5-year period. However, phosphate index at both reservoirs in the month of January was high whilst, sulphates demonstrated a continuing decrease in spatial distribution from 1993-1997.

A study by Bosque-Hamilton et al. (2004) found that cationic pattern of the Weija reservoir was similar to sea water and this can be related to its proximity to the sea. It was also revealed that the reservoir had more aquatic weeds as it was evidenced by dominancy of nutrient with highest nutrient level recorded in the wet season. The Weija reservoir happened to be aerated as a result of it being well mixed, yet less transparent with high phytoplankton abundance.

Many years after human encroachment within the DRB and also around the catchment of the Weija reservoir, it is very worthy to analyze trends of parameters that determine the quality of water found in the Weija reservoir. Thus questions such as, what has been the trend in water quality parameters and what has been some of the existing relationships between these parameters of raw water over a 14-year period were deemed necessary to be answered. It is in this light that this study was embarked upon.

\section{Profile of Study area}

The Weija Reservoir (Fig. 1) (0o 20' W 0o 25' W and 5o 30' N 5o 45' N) was created in 1977 as a replacement for an earlier one which was washed away in 1968 by Ghana Water Company Limited (GWCL) through damming River Densu mainly to satisfy the demand for potable water supply. The Weija reservoir, located about $17 \mathrm{~km}$ west of Accra, is almost at the mouth of River Densu which is $116 \mathrm{~km}$ long and takes its source from the AtewaAtwiredu mountain range in the Eastern Region of Ghana. The current reservoir provides water to western parts of Accra, supports irrigation projects, as well as fisheries.

The Weija reservoir is $14 \mathrm{~km}$ long, $2.2 \mathrm{~km}$ wide and has a total surface area of $38 \mathrm{~km} 2$ with mean depth of 5 $\mathrm{m}$ (Vanden \& Bernacsek, 1990). The normal surface elevation is estimated at $14.37 \mathrm{~km}$ with maximum of 15.24 $\mathrm{km}$ (Nukunya \& Boateng, 1979). The reservoir area is low lying with undulating topography and isolated ridges. Climatic conditions are tropical with temperature averaging $27^{\circ} \mathrm{C}$. Rainfall is moderate with the seasonal average being $65.5 \mathrm{~mm}$. The catchment of the reservoir lies in the coastal savanna zone where rainfall is seasonal, with two rainfall peaks in June and September, while dry periods span between December and March. The main economic activities in the catchment are fishing and crop farming, major crops include maize, cassava, sugarcane and vegetables. Some other activities such as bricks and ceramics making, small scale gold mining and sand mining also go on within the basin.

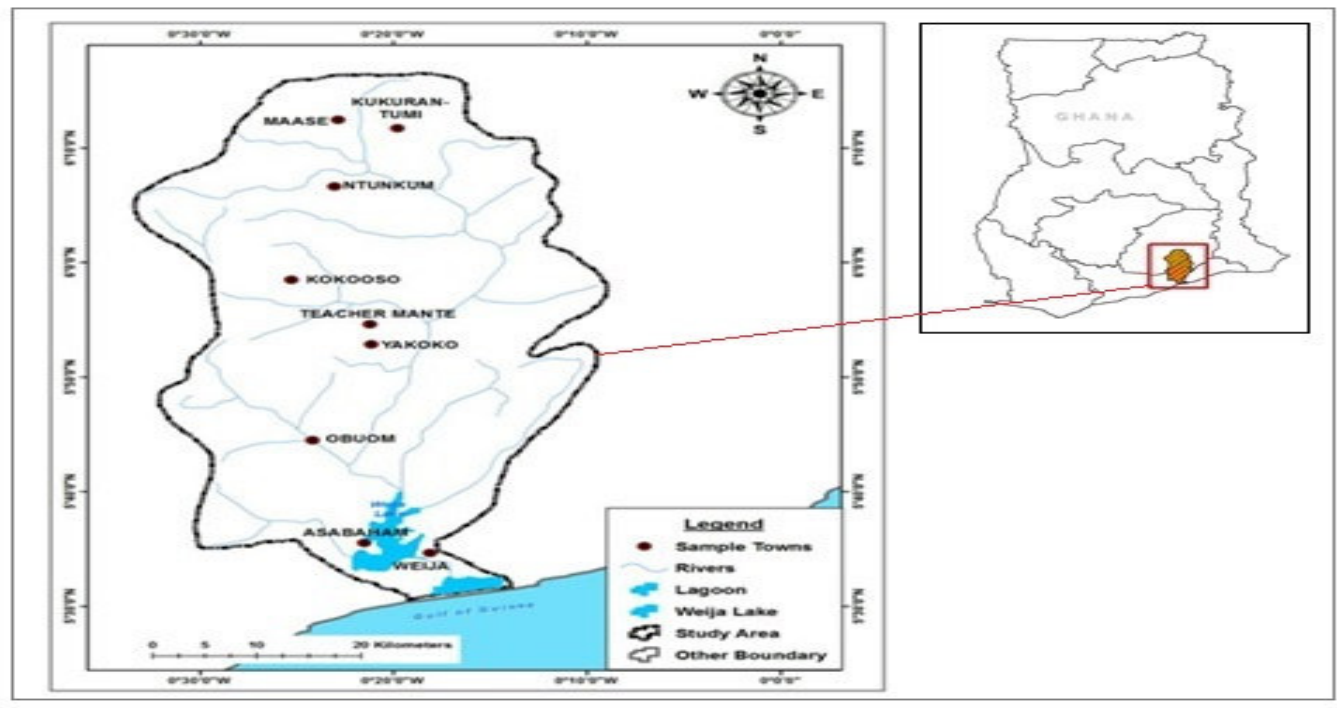

Source: Water Resources Commission (WRC), (2000)

Figure 1: River Densu showing some communities and the Weija reservoir 


\section{Materials and methods}

\subsection{Sources and Types of Data}

Secondary type of data was utilized in this study. The secondary data included data on water quality parameters which were all physio-chemical (Phosphate, Nitrate, Ammonia, Turbidity, Colour, pH, Temperature, Sulphate, Iron, fluoride, Total solids, Suspended Solids, Total Dissolved Solids, total hardness, Calcium, and Manganese) from the Weija Head Works.

\subsection{Sampling of physio-chemical parameters}

This study was conducted in 2017 and involved 16 water quality parameters, namely Phosphate, Nitrate, Ammonia, Turbidity, Colour, pH, Temperature, Sulphate, Iron, Fluoride, Total Solids, Total Suspended Solids, Total Dissolved Solids, Total Hardness, Calcium and Magnesium. These were parameters with consistency in recordings throughout the 14 years.

\subsection{Statistical Analysis}

Statistical analysis of the data on water quality parameters was done using Microsoft Excel. Descriptive summary statistics such as yearly mean concentration as well as graphs were generated. The yearly mean values were compared with the water quality guideline of the World Health Organization (WHO, 2011).

\section{Results}

\subsection{Phosphate}

From Figure 2, the highest average phosphate content in the Weija reservoir was recorded in the year 2015 which was $10.9 \mathrm{mg} / \mathrm{L}$ whilst 2013 recorded the lowest average phosphate content of $0.1 \mathrm{mg} / \mathrm{L}$. The other remaining years recorded very minimal average recordings which were slightly above the average recordings of 2013.

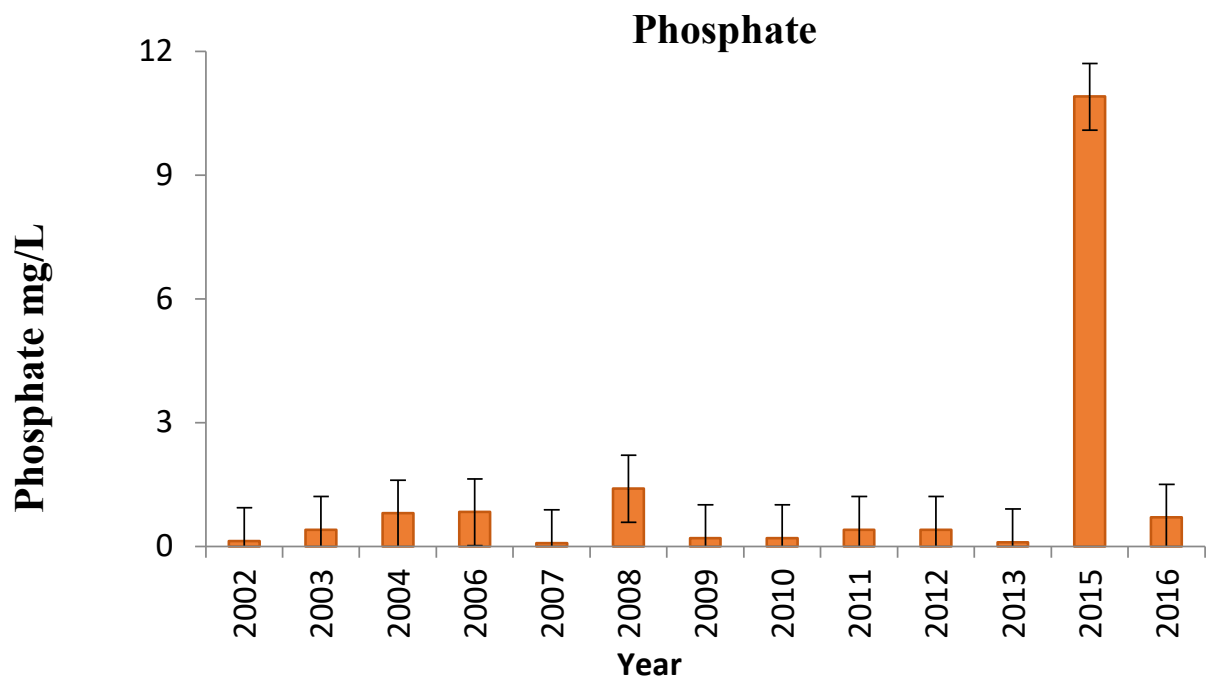

Figure2: Level of phosphate in raw water (no guideline value)

Source: Data on water quality parameters from WHW

\subsection{Nitrate}

Findings revealed that, in 2003 and 2015, nitrate recorded high levels of $3.9 \mathrm{mg} / \mathrm{L}$ and $4.9 \mathrm{mg} / \mathrm{L}$ respectively while in 2006, 2011, 2012 and 2013, the nitrate level was very negligible. It could also be observed that nitrate levels started decreasing in 2008 through to 2013 after which it increased in the years 2015 and 2016. 


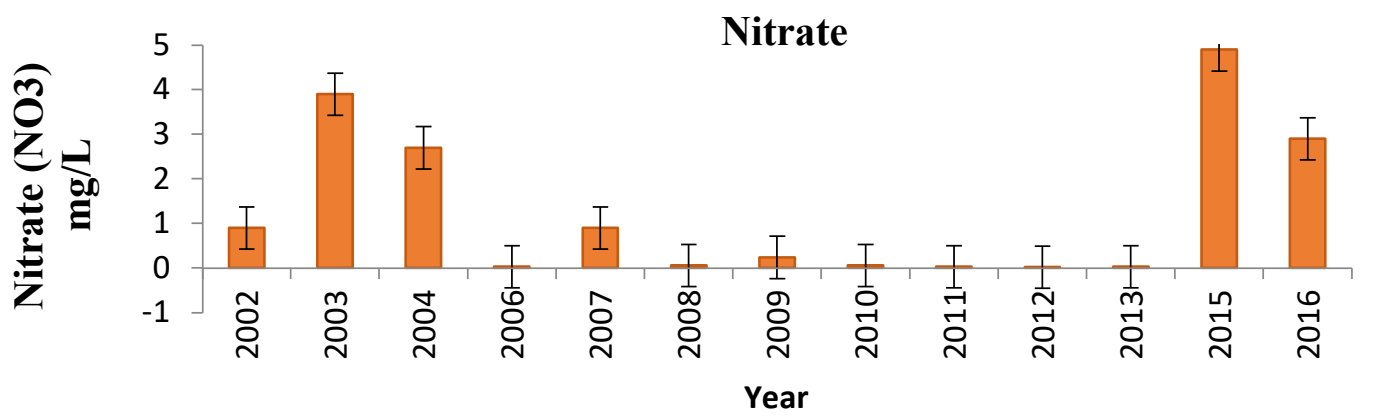

Figure 3: Level of nitrate in raw water (WHO max. $-50 \mathrm{mg} / \mathrm{L}$ )

Source: Data on water quality parameters from WHW

\subsection{Ammonia}

The record shows that, in 2012, the level of ammonia in the water was $0.6 \mathrm{mg} / 1 \mathrm{which}$ represented the highest average recording year while in 2015 and 2016, ammonia was either null or very insignificant. It could also be observed that ammonia increased in 2003 and 2004 while its content in the water started decreasing from 2008 through to 2011. Although the highest average content was recorded in 2012, ammonia content in the water decreased tremendously in the years 2013, 2015 and 2016.

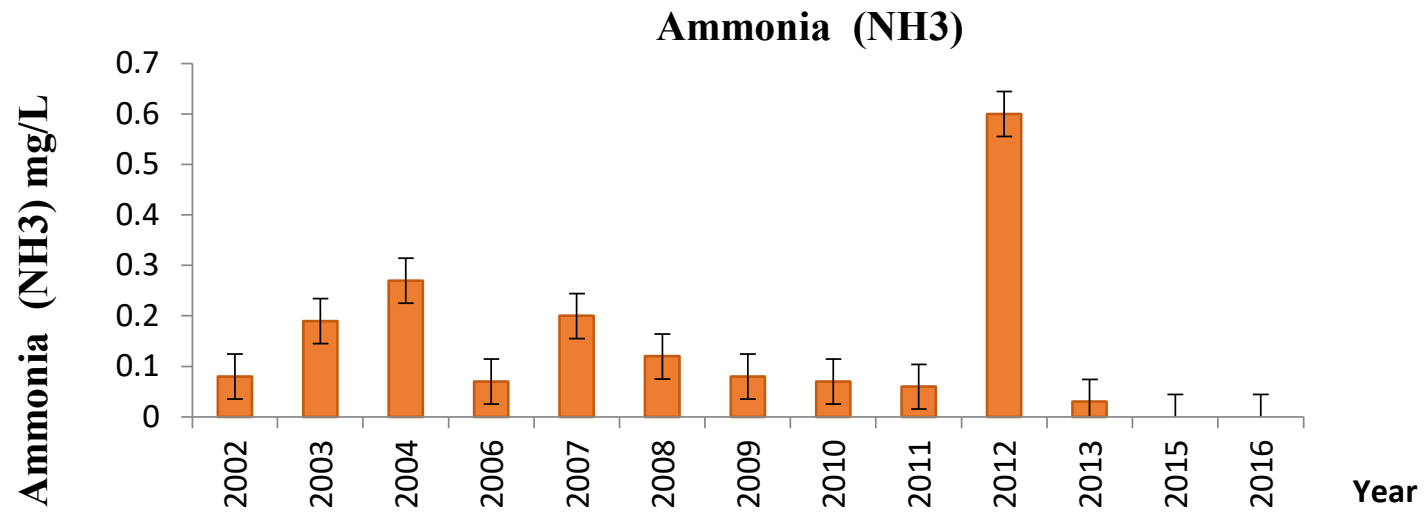

Figure 4: Level of ammonia in raw water (WHO max. - 1.5mg/L)

Source: Data on water quality parameters from WHW

\subsection{Turbidity}

Figure 5 indicates average levels of turbidity in raw water from the Weija reservoir from 2002-2016. The figure shows that 2003 and 2004 recorded the highest levels of turbidity with recordings being 25 NTU and 21.9 NTU respectively while 2013 recorded 7.4 NTU which happened to be the lowest recording.

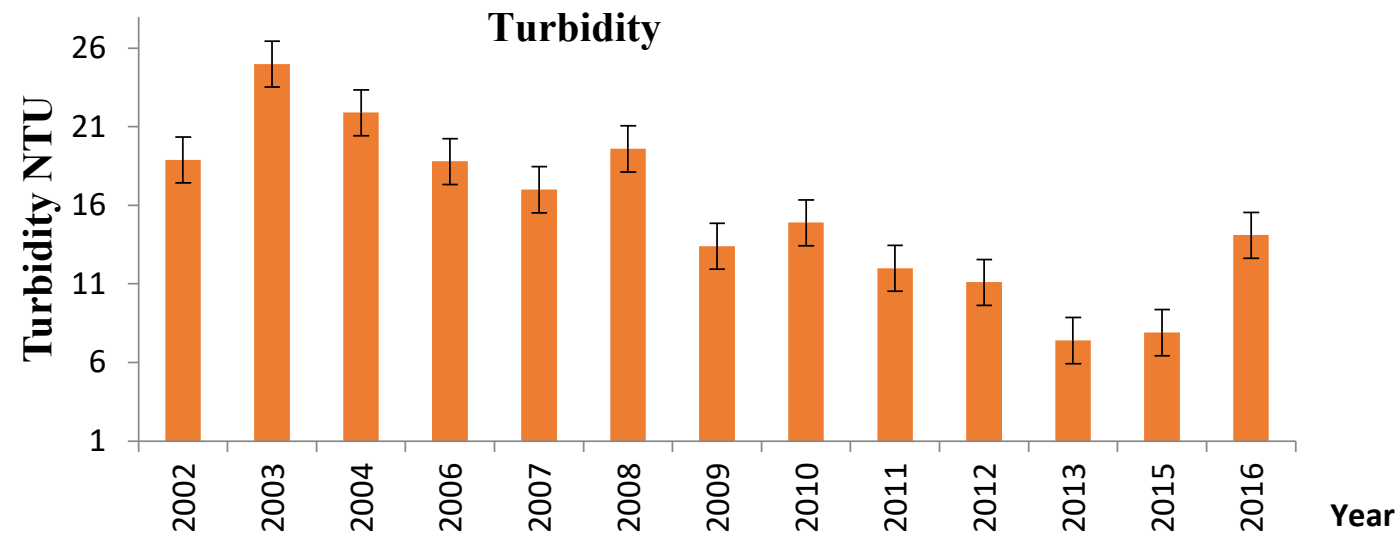

Figure 5: Level of turbidity in raw water (WHO max. - 5 NTU)

Source: Data on water quality parameters from WHW 


\subsection{Colour}

Figure 6 below indicates the colour of raw water recorded from 2002 to 2016. It was realized that average levels of water colour were very high as compared to what the World Health Organization has established (15 TCU). The figure shows that the highest average recording was made in 2003 which was 157 TCU while in 2015, it was observed that the colour level had reduced to 68 TCU. It can also be observed from the Figure 5 that after 2009, the level of colour of water kept on improving.

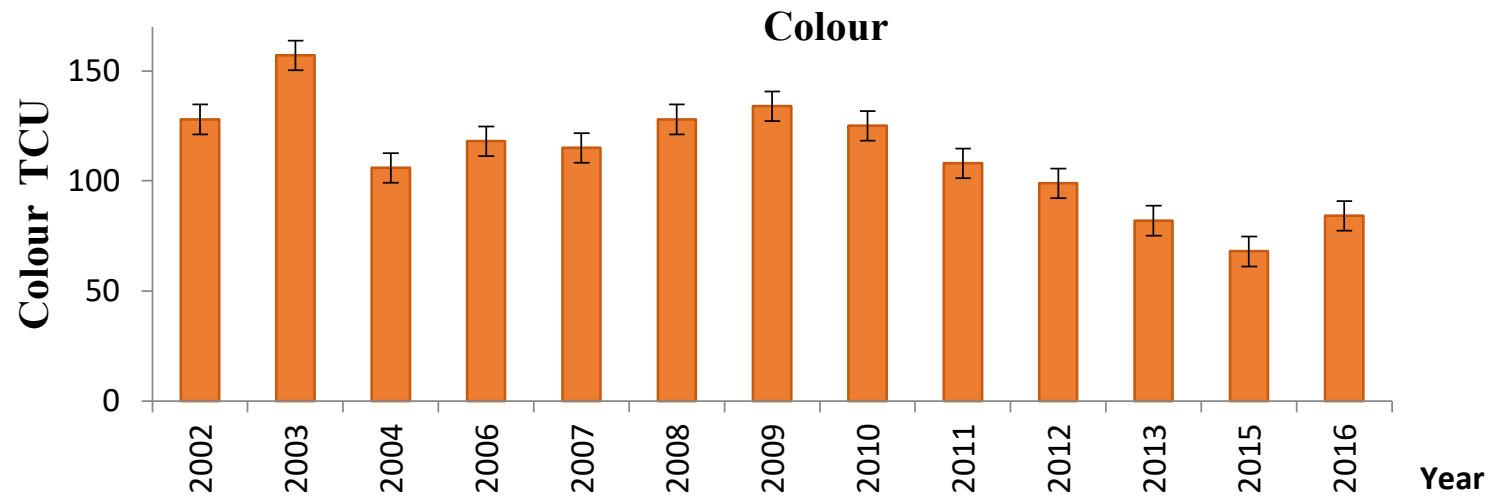

Figure 6: Level of colour (apparent) in raw water (WHO max.-15 TCU)

Source: Data on water quality parameters from WHW

\section{6 pH}

Figure 7 indicates the levels of $\mathrm{pH}$ of raw water samples from 2002 -2016. In 2002, 2004 and 2015, the level of $\mathrm{pH}$ was high at 7.9 while in 2006, 2007, 2008 and 2011, pH recorded a lower value of 7.5.

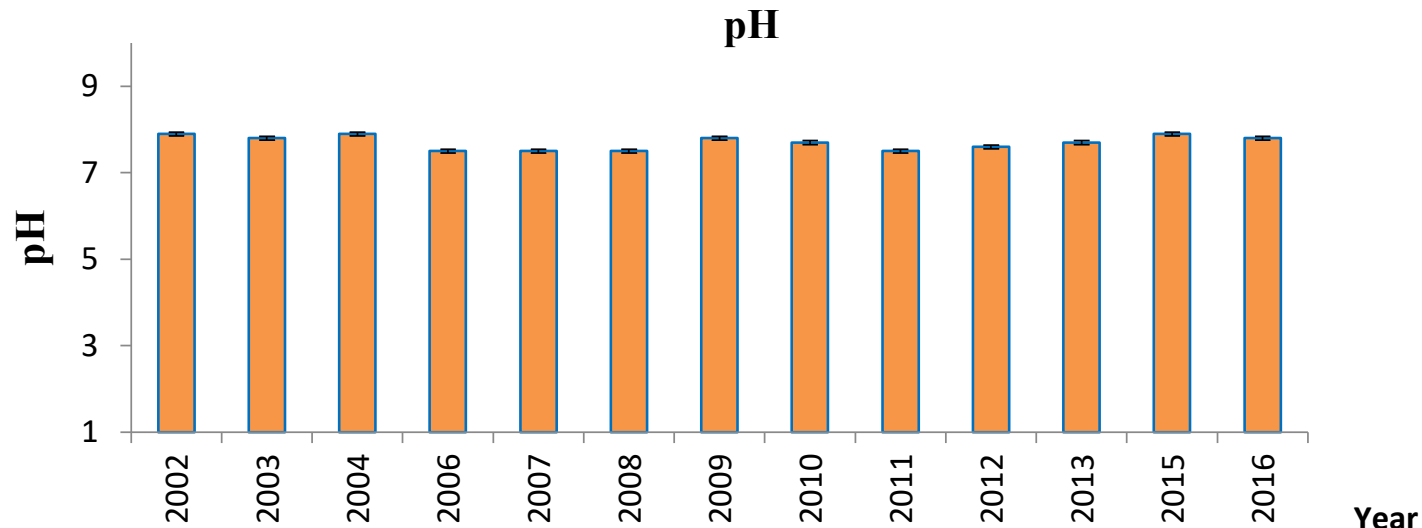

Figure 7: Level of $\mathrm{pH}$ in raw water (WHO min. 6.5- max. 8.5)

Source: Data on water quality parameters from WHW

\subsection{Temperature}

It was observed that the results of analysis for temperature fell between the ranges of $25.6-28.7$ degree Celsius and it is represented graphically below:
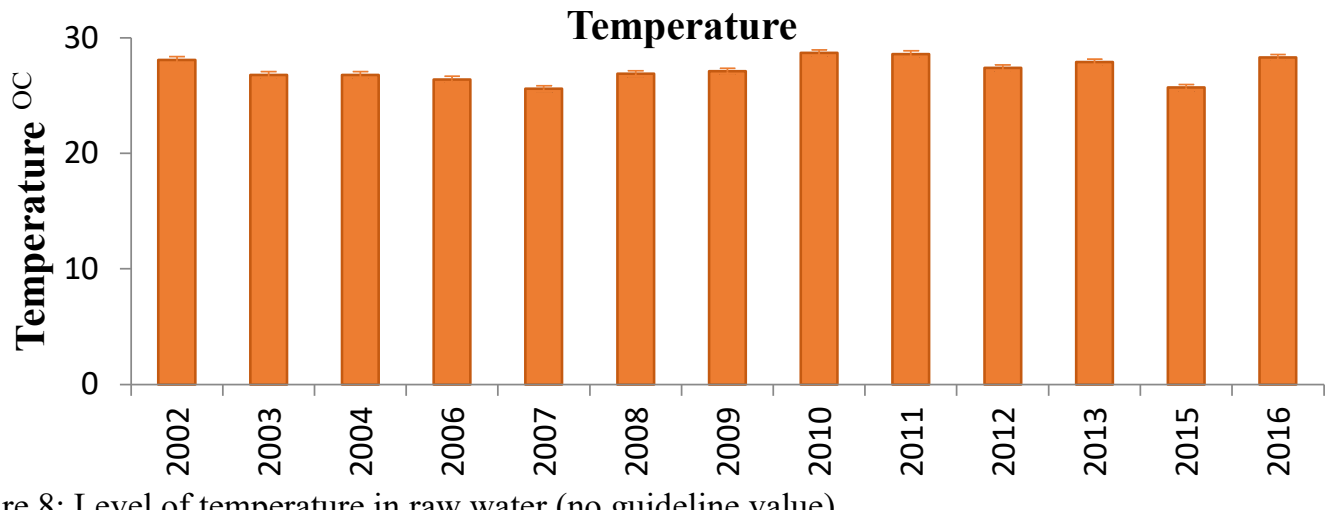

Figure 8: Level of temperature in raw water (no guideline value) Source: Data on water quality parameters from WHW 


\subsection{Sulphate}

Figure 9 indicates a presentation of yearly average levels of sulphate present in raw water samples from 2002 2016. The lowest average recordings were made in 2002 and 2007 whilst the highest was made in 2003. The figure clearly shows that sulphate recorded very low levels of less than $50 \mathrm{mg} / \mathrm{L}$ throughout the 14 years.

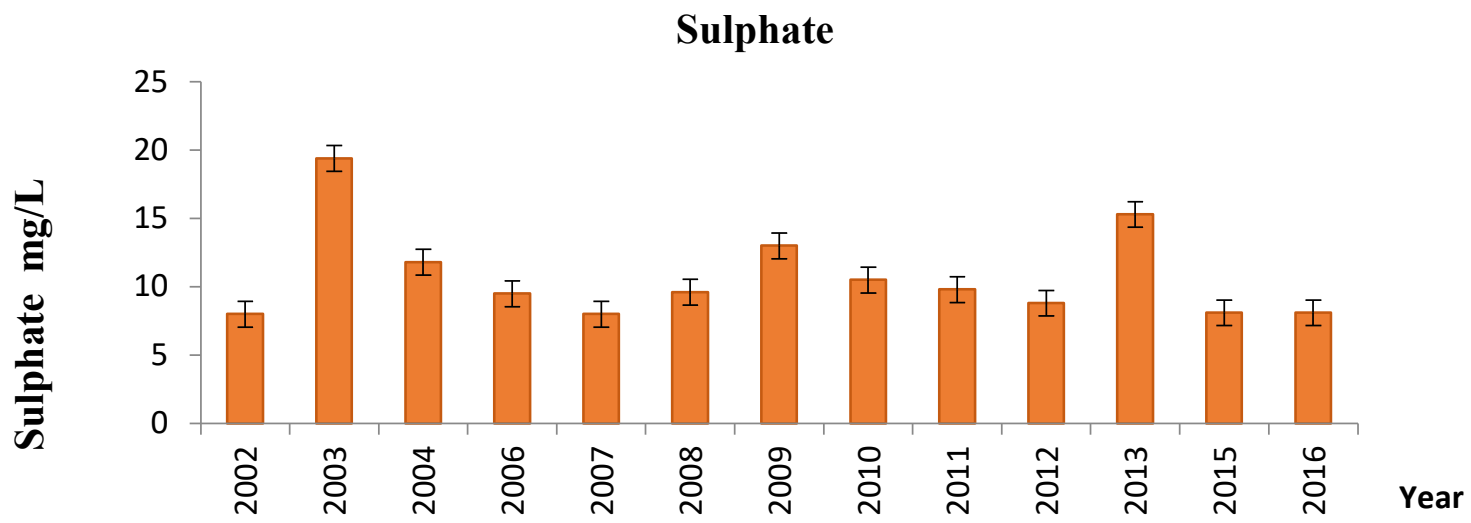

Figure 9: Level of sulphate in raw water (WHO max $-500 \mathrm{mg} / \mathrm{L})$

Source: Data on water quality parameters from WHW

\subsection{Iron}

Figure 10 indicates the iron levels in raw water analyzed from 2002 to 2016. It was revealed that, in 2012, the highest average level of iron $(1.7 \mathrm{mg} / \mathrm{L})$ in water from the Weija reservoir was recorded. The record also shows that the second highest recording was made in 2015 which was $0.3 \mathrm{mg} / \mathrm{L}$ while in the remaining years, iron levels were very low.

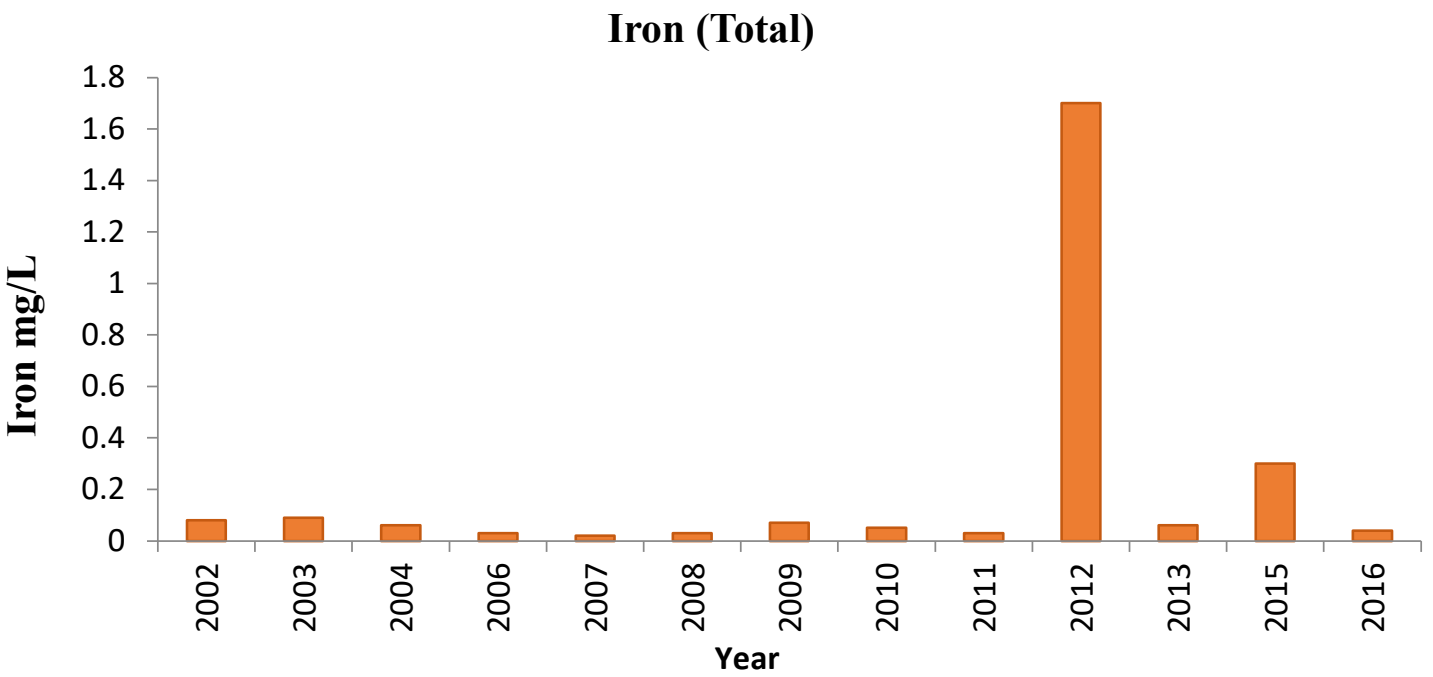

Figure 10: Level of iron (total) in raw water (WHO max. $-0.3 \mathrm{mg} / \mathrm{L}$ )

Source: Data on water quality parameters from WHW

\subsection{Fluoride}

It can be observed from Figure 11 that recordings for fluoride fell within the WHO guideline values. In 2015, 2003, 2004 and 2007, fluoride levels in water from the Weija reservoir were higher than other years. The figure also shows that, in some years, such as 2002, 2012 and 2016, the level of fluoride in the water was negligible. 


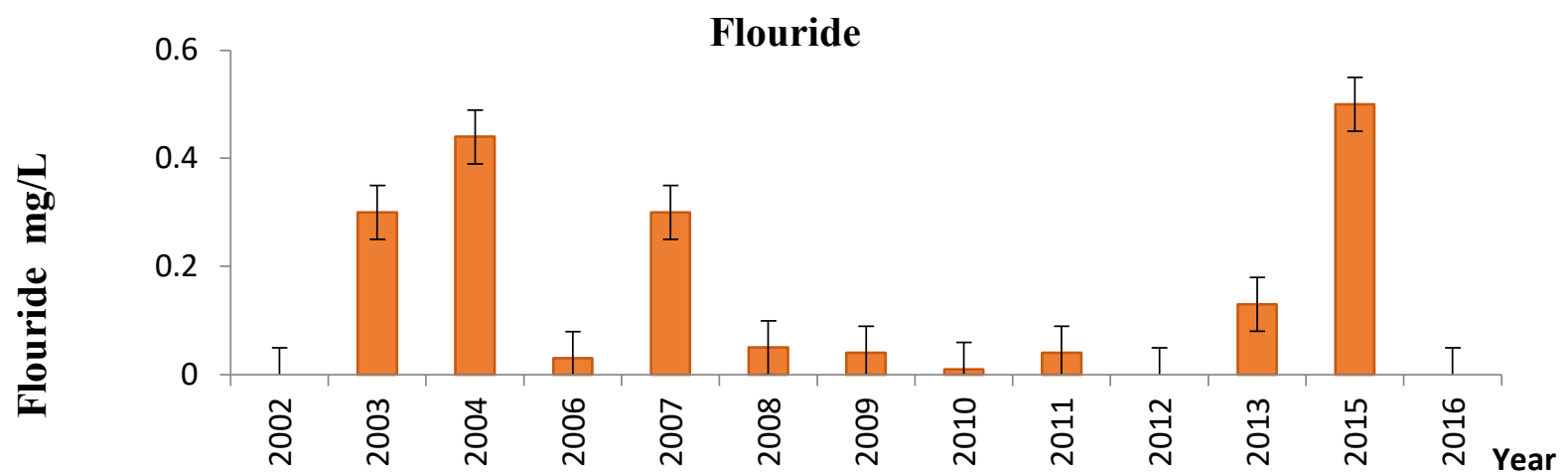

Figure 11: Level of fluoride in raw water (WHO max. $-1.5 \mathrm{mg} / \mathrm{L}$ )

Source: Data on water quality parameters from WHW

\subsection{Total Solids}

It can be seen from Figure 12 that the average recordings of total solids were all bellow the $1000 \mathrm{mg} / \mathrm{L}$ max value established by WHO. It can also be observed that the lowest average Total Solids content was recorded in the year 2002 which was $120 \mathrm{mg} / \mathrm{L}$ while the highest content was recorded in 2016 which was $220 \mathrm{mg} / \mathrm{L}$.

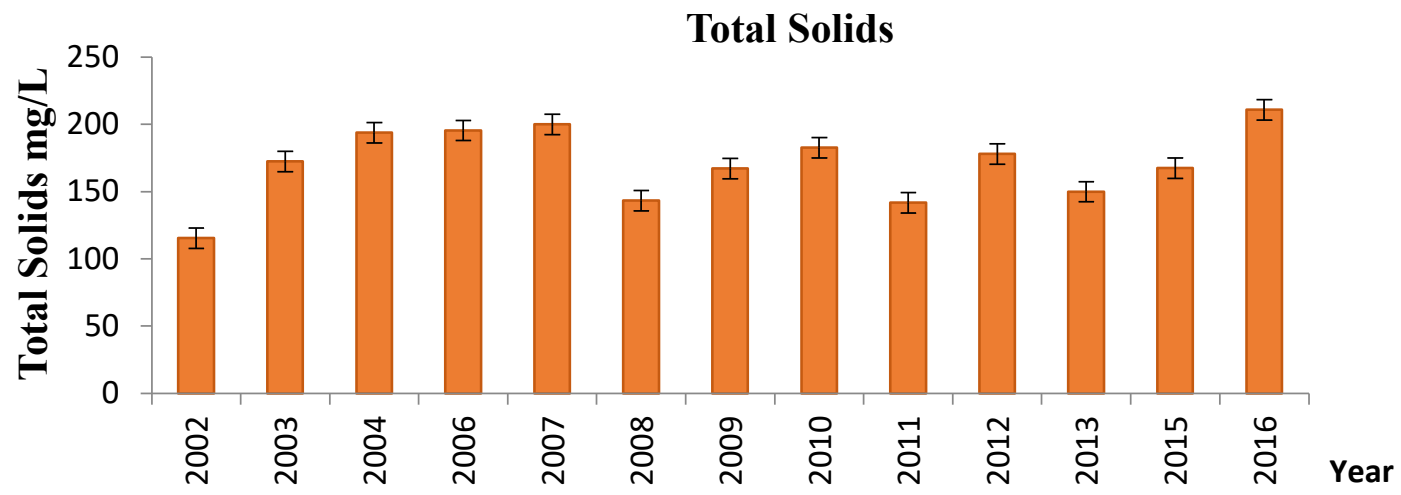

Figure 12: Level of total solids in raw water (WHO max. $-1000 \mathrm{mg} / \mathrm{L}$ )

Source: Data on water quality parameters from WHW

\subsection{Suspended Solids}

Deductions from Figure 13 inform that among the 14 years, 2011 recorded the least level of suspended solids whilst 2016 recorded the highest concentration. It is also revealed that after 2004, suspended solids level started decreasing through to 2012 after which its constituent started increasing from 2013 through to 2016.

\section{Suspended Solids}

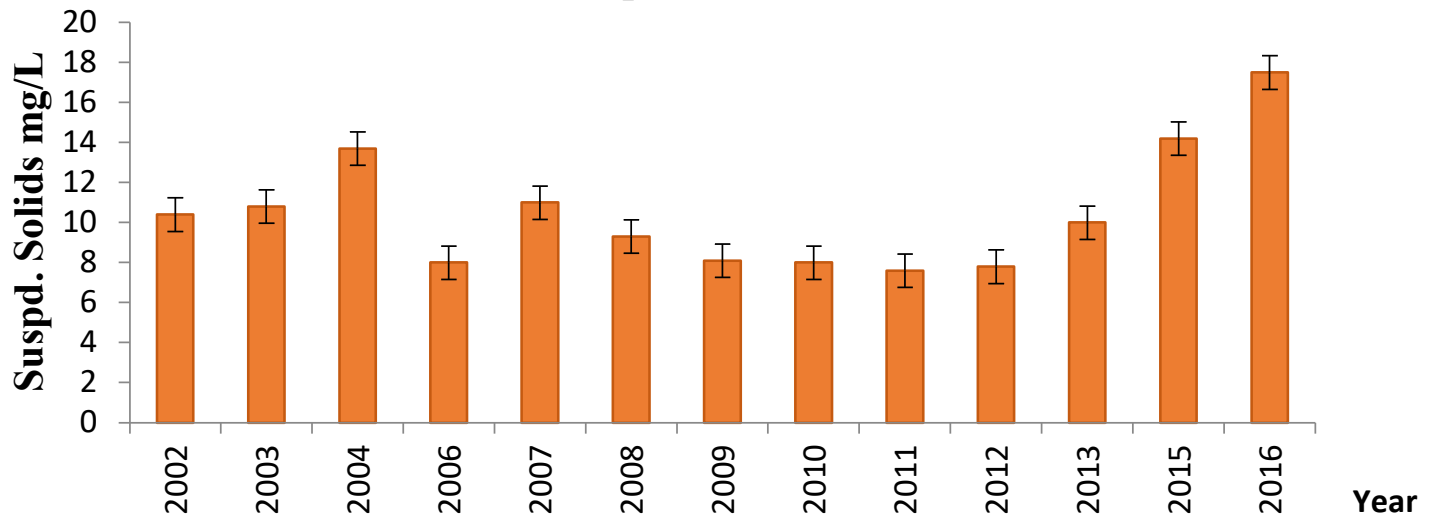

Figure 13: Level of suspended solids in raw water (no guideline value).

Source: Data on water quality parameters from WHW 


\subsection{Total Dissolved Solids}

Figure 14 gives an account of the level of TDS in water which was recorded from 2002 to 2016 . The figure depicts that, 2002 and 2008 recorded low levels of total dissolved solids, being $109.8 \mathrm{mg} / \mathrm{L}$ and $133.1 \mathrm{mg} / \mathrm{L}$ respectively while 2004 and 2016 recorded higher levels of $196.8 \mathrm{mg} / \mathrm{L}$ and $193.5 \mathrm{mg} / \mathrm{L}$ respectively.

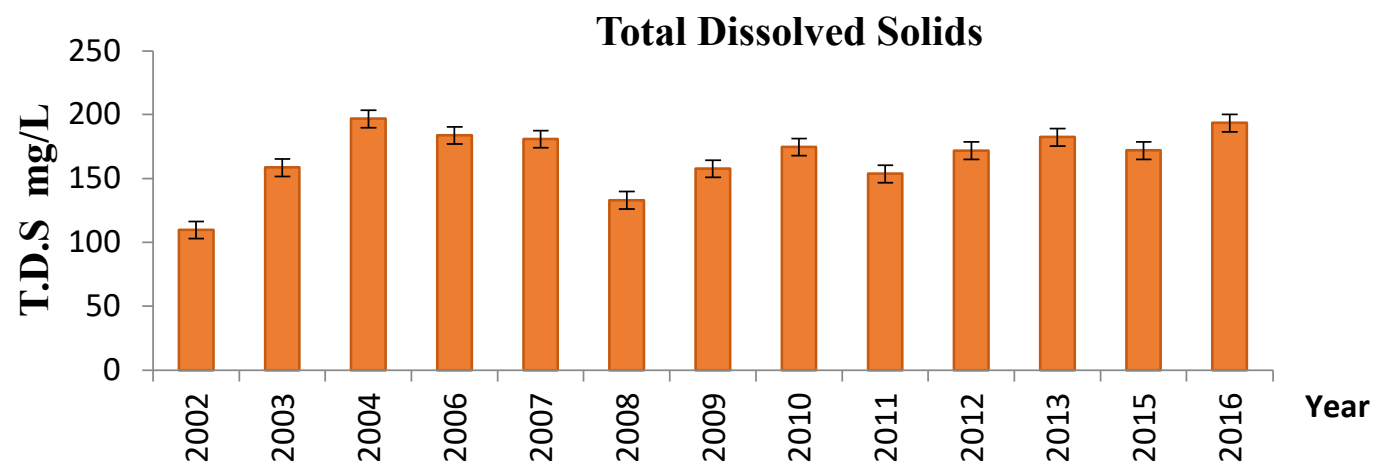

Figure 14: Level of T.D.S in raw water (WHO. Min. $500 \mathrm{mg} / \mathrm{L}-\max .1000 \mathrm{mg} / \mathrm{L}$ )

Source: Data on water quality parameters from WHW

\subsection{Total Hardness}

Figure 15 illustrates the average levels of hardness of water that were recorded from the Weija reservoir for a period of 14 years. The figure shows that the level of hardness attained its highest yearly average recording in 2016 which was $120 \mathrm{mg} / \mathrm{L}$ while the remaining years had recordings between $60 \mathrm{mg} / \mathrm{L}$ and $97.7 \mathrm{mg} / \mathrm{L}$. It could be observed from the figure that the level of hardness in the water started decreasing after 2002 through to 2007, after which it started increasing in 2008 through to 2016.

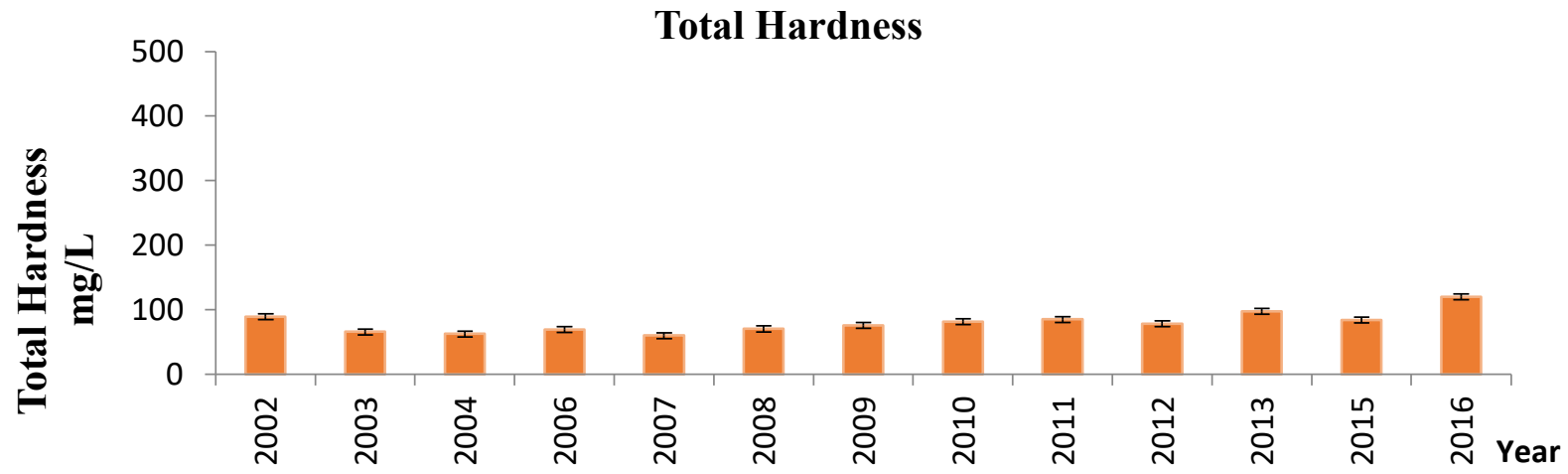

Figure 15: Level of total hardness in raw water (WHO max. $-500 \mathrm{mg} / \mathrm{L}$ )

Source: Data on water quality parameters from WHW

\subsection{Calcium}

Observations from Figure 16 below show that the results from the recordings for calcium fell within WHO guideline value except for 2007 which recorded $158.4 \mathrm{mg} / \mathrm{L}$. It was also revealed that the calcium content in the water started decreasing in 2003 through to 2007, after which it tremendously dropped in 2008 but subsequently started increasing afterwards. 


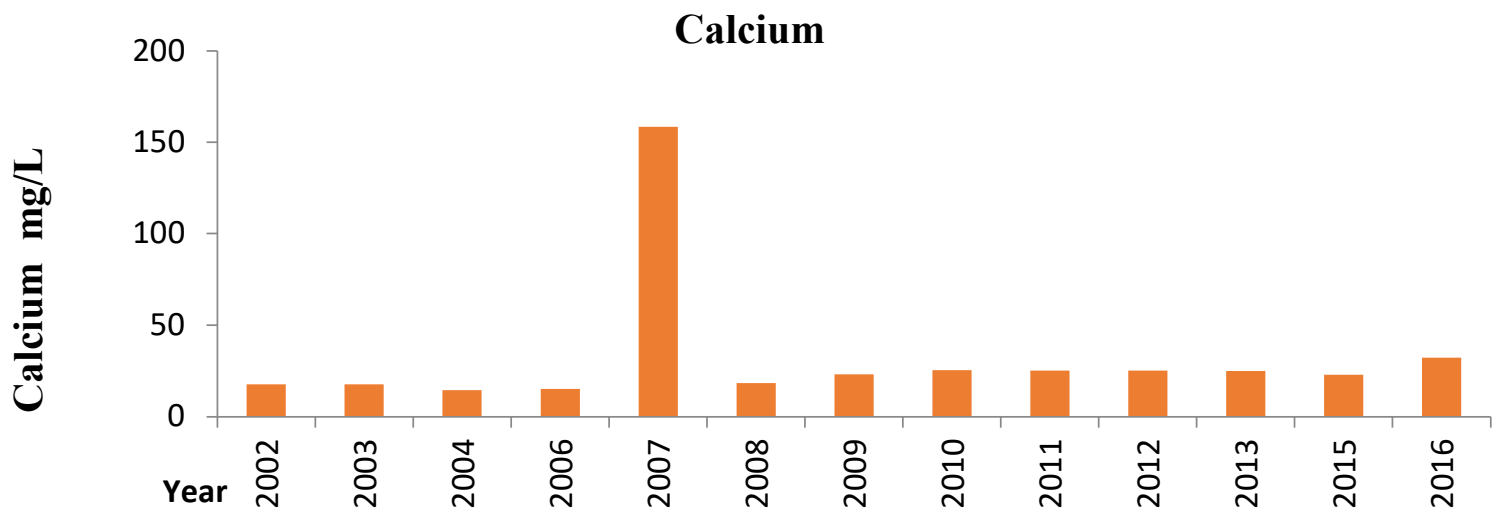

Figure 16: Level of calcium in raw water (WHO max. - 50mg/L)

Source: Data on water quality parameters from WHW

\subsection{Magnesium}

It was observed that among the 14 years, 2016 recorded the highest magnesium content which was $11.9 \mathrm{mg} / \mathrm{L}$ while 2010 recorded the lowest magnesium content at $4.4 \mathrm{mg} / \mathrm{L}$. It was further observed that recordings decreased drastically after 2003 through to 2011, after which it started increasing through to 2016.

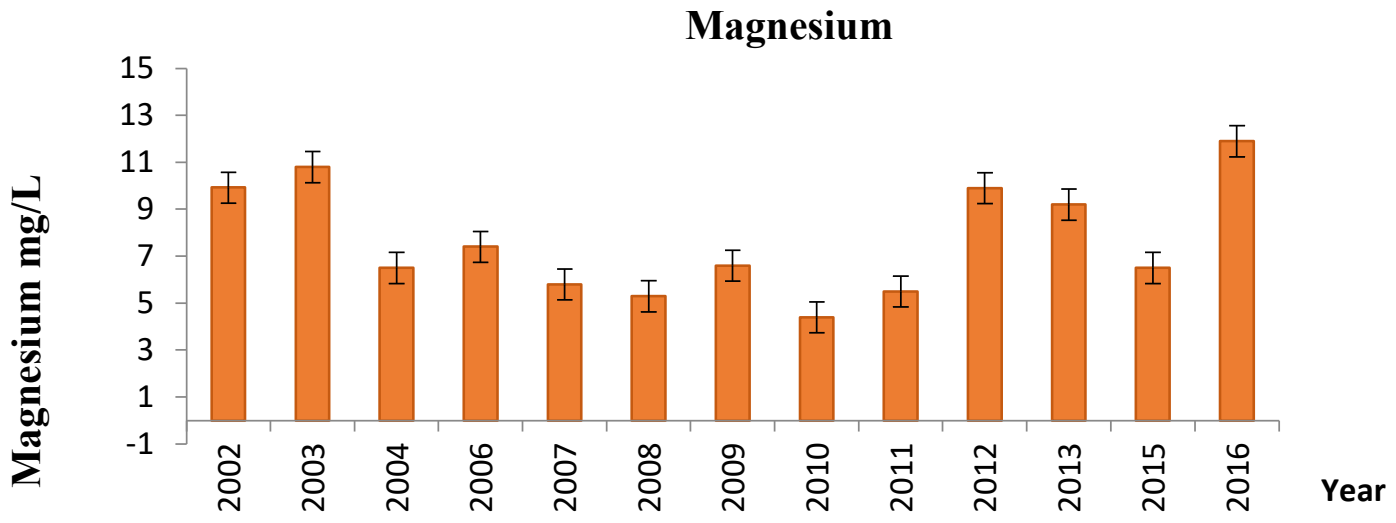

Figure 17: Level of magnesium in raw water (WHO max. - 30mg/L)

Source: Data on water quality parameters from WHW

\section{Discussions}

\subsection{Phosphate, Nitrate and Ammonia}

Excessive quantities of phosphate accelerate algae and plant growths in natural waters, thereby enhancing eutrophication and reducing oxygen levels in the water. The data showed that the results of the phosphate analysis were very low during the period under study.

The highest phosphate concentration was recorded in 2015 with an average value of $10.9 \mathrm{mg} / \mathrm{L}$ (see Figure 2) and this was far below WHO's concern that phosphate concentrations beyond $100 \mathrm{mg} / \mathrm{L}$ is considered as excess and may interfere with coagulation processes in water treatment plants (WHO, 2011). Results from Figure 2 also demonstrated that phosphate contributed very little to eutrophication (algal production) on the water surface as indicated by Fadiran et al (2008) that too much phosphates concentration in water results in high rate of eutrophication.

The nitrate concentration in the Weija reservoir was found to be in the acceptable limit $(10 \mathrm{mg} / \mathrm{L})$ i.e. between the ranges of $0.02 \mathrm{mg} / \mathrm{L}$ to $4.9 \mathrm{mg} / \mathrm{L}$ within the years chosen for the study. The highest nitrate value $(4.9 \mathrm{mg} / \mathrm{L}) \mathrm{was}$ recorded in 2015 with the least recording $(0.02 \mathrm{mg} / \mathrm{L})$ in 2012 . It could also be observed that the nitrate level started declining from 2008, through to 2013, after which there was a drastic increase in 2015 and a sudden decrease in 2016. This pattern of occurrence is similar to that of phosphate which also ends up in water through human activities and agricultural runoffs. The low recordings of nitrate for the 14 years indicated that water from the Weija reservoir is somehow free from bacterial contamination as stipulated by WHO (2007), that high levels of nitrate in drinking water is often associated with the simultaneous presence of bacterial contamination. Also, consumers of water from the Weija reservoir are believed to be less infected by a condition known as 
methaemoglobinaemia, which, according to WHO (2006), is when blood lacks the ability to carry sufficient oxygen to the individual body cells which may cause the skin and veins to appear blue, and this condition happens when nitrate is converted to nitrite and reacts with iron in the hemoglobin of the red blood cells.

Ammonia is not of any direct relevance to health at levels within which they occur in water bodies, and no health-based guideline value has been proposed. However, ammonia does react with chlorine to reduce free chlorine and to form chloramines which contribute to odour and taste problems in water (WHO, 2011). The ammonia content in the Weija reservoir had very low readings as compared to the World Health Organization's standard of $1.5 \mathrm{mg} / \mathrm{L}$. The record showed that in 2012, the level of ammonia in the water sample was $0.6 \mathrm{mg} / \mathrm{L}$, which represents the highest recording year while in 2015 and 2016, ammonia recordings were either null or very insignificant. There was an increase in ammonia concentration in 2003 and 2004 while its content in the water started declining in 2008 through to 2011 . Again, there was a drastic increase from $0.06 \mathrm{mg} / \mathrm{L}$ in 2011 to $0.6 \mathrm{mg} / \mathrm{L}$ in 2012. The sudden increase could be linked to increased industrial and agricultural activities around the water course since concentration of ammonia in water could come from industrial, domestic, agricultural pollution; mainly from fertilizers and organic matters (www. Scribd.com). Although the highest average content was recorded in 2012, ammonia content in water decreased tremendously in the years 2013, 2015 and 2016.

The low value recordings of the above parameters over the years could be as a result of a decrease in farming activities in general or a decreased/proper means of fertilizer application and proper liquid waste management of the increasing population in the DRB. The above discussions confirm the assertion made by USESB (2003) that phosphates, nitrate and ammonia are often at minimal values if proper industrial and household discharge, fertilizers and pesticides applications are made.

\subsection{Colour, Turbidity and Iron}

Colour in drinking-water is generally due to the presence of suspended and dissolved particles. Colour is also intensely influenced by the presence of metals such as iron. The colour patterns from $2002-2004$ and 2007 2011 had a similar trend to that of iron concentrations in the water; as the level of iron increased, the colour level also increased and this could signal an influence of iron on colour of the water. Thus, the colour of the water was positively related to the presence of iron.

There were some few instances where the colour was highly influenced by the presence of high level of total solids. There was a rise in the colour from $106 \mathrm{TCU}$ in 2004 to $118 \mathrm{TCU}$ in 2006, being as a result of increased concentrations of the total solids in the reservoir. Noticeably, there was a decrease in colour in the $2012-2013$ periods and a sudden rise in the 2015 - 2016 periods; these recordings were influenced by the patterns of iron and total solids respectively. It was realized that average levels of colour of water in the Weija reservoir were very high as compared to the World Health Organization's guideline of 15 TCU. This was evident when in 2015, the least colour level was recorded as 68 TCU. Though the values were beyond the WHO's set guideline, it was seen from the results that the colour levels kept improving from 2011 until 2016 when it suddenly rose to 84.1 TCU due to high presence of total solids. The fluctuation was as a result of the various activities around the river which influenced the presence of iron and the total solids concentrations in the water.

The turbidity levels in the Weija reservoir were very appalling as the values recorded were all beyond the WHO set guideline of 5 NTU (Nephelometric Turbidity Unit). Figure 5 showed a sudden increase in the average turbidity from 18.9 NTU in 2002 to 25 NTU in 2003, with this being the highest value for the study period. The least turbidity value was recorded in 2013 which was 7.4 NTU. After the sweeping rise in 2003, there was an improvement in the turbidity values over time. High levels of turbidity throughout the 14 years showed that there were too much particulate materials as indicated by Putz (2003) that particulate materials such as clay or silt, plankton and finely divided organic matter increase the level of turbidity of water.

Though the quality of the water in terms of turbidity had been improving since 2003 , it is very essential to pay much attention to it as it contributes extra cost to treatment of the water. It also affects light available to aquatic organisms as it is indicated by Stanistski et al. (2000) that high level of water turbidity result to high degree of light scattering by suspended particles such as clay or silt. The turbidity levels were as influenced by the presence of iron and suspended particles. It was seen from Figure 5 and Figure 10 that the pattern of occurrence of the iron concentration in the water was the same as that of the turbidity. Turbidity level was increasing with the increase in iron and vice versa from $2002-2008$. During this period, the turbidity was influenced by iron. The pattern changed for the subsequent years due to several factors including the presence of suspended solids. Suspended Solids was the major contributor to the turbidity of the water from 2010 through to 2016 . These high readings of turbidity and colour of water from the Weija reservoir could be attributed to the persistence of stone quarrying, sand mining and galamsey activities that take place at the north eastern part of the basin. The increase in such activities could be linked to the consistent increase in human population within the basin.

The presence of iron in water has no direct health impact on consumers, but it can be a worrying chemical in water supplies. When ferrous iron oxidizes to ferric iron, it gives an objectionable reddish-brown colour to the water when exposed to the atmosphere (WHO, 2011). The dissolved ferrous iron gives water a displeasing metallic 
taste. The presence of iron in water promotes the growth of "iron bacteria" which deposits a reddish brown or yellow slime that can result in an offensive odour. Figure 10 indicated that all the study years recorded iron concentrations within the WHO standard of $0.3 \mathrm{mg} / \mathrm{L}$ with the exception of 2012 , which exceeded the WHO guideline with an average iron concentration of $1.7 \mathrm{mg} / \mathrm{L}$. However, recordings in those years were not far from reaching the WHO standard of $0.3 \mathrm{mg} / \mathrm{L}$ and this could be related to all mining activities within the basin, especially at the northern section. Iron concentrations beyond $0.3 \mathrm{mg} / \mathrm{L}$ stains laundry and plumbing fixtures (WHO, 2011). The presence of iron in the reservoir may be due to weathering of iron bearing minerals and rocks such as carbonates and iron clay minerals.

\section{$5.3 \mathrm{pH}$}

Though $\mathrm{pH}$ has no direct health impact on water consumers, it is one of the most significant water quality parameters, as the solubility and bio availability of chemical constituents and heavy metals in water depend on it. The $\mathrm{pH}$ levels of the raw water within the study period were found to be in the acceptable range $(6.5-8.5)$ set by the WHO. The highest pH value recorded was 7.9 and this was recorded in 2002, 2004 and 2015 while the least $\mathrm{pH}$ was recorded in 2006, 2007, 2008 and 2011, with an average of 7.5. Although pH levels were high throughout the years, it could be attested from Figure 6 that all yearly recordings for $\mathrm{pH}$ fell within the optimum $\mathrm{pH}$ range $(6.5-8.5)$ which is said to reduce the solubility of heavy metals in water, hence making it less toxic to aquatic lives (Alabaster \& Lloyd, 1980).

\subsection{Temperature}

Temperature is the degree of hotness or coldness of the water. Cool water is usually more palatable than warm water. However, high water temperature increases the growth of microorganisms and may increase problems related to odour, taste, corrosion and colour (WHO, 2011). The temperature is affected by the presence of suspended solids in the water; the solids absorb sunlight which further heats the water. The presence of the suspended solids may be as a result of the removal of vegetation (due to illegal mining at upstream) near the water source which often results in increased erosion and increased amounts of sediments in the water. Removal of vegetation around the river will increase the heating of the water surface by sunlight. The temperature of the water was between the ranges of $25.6-28.7^{\circ} \mathrm{C}$. Though temperature within this range reduces the solubility of oxygen in the river, it improves the efficiency of disinfection during water treatments as reactions occur more quickly. At lower temperatures, longer contact times or higher concentrations of chemicals are required for disinfection. There are no guidelines for temperature.

\subsection{Sulphate}

The data showed that sulphate concentration was far below the proposed guideline of 500mg/L by the WHO. Though it is of no health concern, elevated sulphate levels together with chlorine bleach can make cleaning of clothes very difficult. Excessive sulphate may cause laxative effect and can promote the growth of sulphuroxidizing bacteria with effects similar to those of iron bacteria. The highest sulphate concentration was recorded to be $19.4 \mathrm{mg} / \mathrm{L}$ in 2003 with the least value, $8 \mathrm{mg} / \mathrm{L}$, recorded in 2002 . Though the values were far below the guideline set by WHO (ma. $500 \mathrm{mg} / \mathrm{L})$, there were variations throughout the study period. Population, built up and farming activities keep on increasing in the basin, yet sulphate levels kept on remaining very low. This result is in disagreement with an assertion made by Okeola, Kolawole and Ameen (2010) that the increase in human population and activities such as domestic and industrial outings end up increasing sulphate concentration in water. The above discussion can therefore help to conclude that sulphate concentration in the Weija reservoir was of a more natural introduction than as a result of human works, and this is in a consensus by Silberberg (2000) that sulphate occurrence in water often happens naturally through water runoffs from many soil and rock formations.

\subsection{Fluoride}

Fluoride is very vital in drinking-water in order to shield human tooth against cavities (WHO, 2011) but it can be harmful when it exceeds its limits. The fluoride concentrations in the Weija reservoir for the study period were observed to be within the WHO's guideline value of $1.5 \mathrm{mg} / \mathrm{L}$. It was observed from Figure 11 that there were insignificant fluoride concentrations in the 2002, 2012 and the 2016 study years. The highest values recorded in 2003, 2004 and 2015 give an indication of an increase in activities such as bricks and ceramics making within the DRB as indicated by the WHO (1984), these activities are among the important sources of fluoride. Since the average concentration was $0.5 \mathrm{mg} / \mathrm{L}$ and it falls within the acceptable limit, it makes the water good in terms of fluoride occurrence as concentrations above $1.5 \mathrm{mg} / \mathrm{L}$ has higher risk of dental fluorosis with which increasingly higher concentrations can lead to risks of skeletal fluorosis (WHO, 2011).

\subsection{Total Solids (Suspended Solids and Dissolved Solids)}

Total solids, TS, comprise total of all the suspended and dissolved solids in a sample of water. Natural water carries 
many dissolved and un-dissolved solids. The presence of solids in water affects its quality. The analysis indicated that the solids in the water contributed highly to the occurrence of turbidity, colour, and change in temperature. A comparison of Figure 14 (TDS) and Figure 13 (TSS) against Figure 12 (TS) showed very clearly that TS levels in the Weija reservoir were greatly influenced by both TSS and TDS as they had corresponding trends.

Though the WHO and GSBA have no guideline values for suspended solids, the GSBA advices that water for drinking should have no amount of suspended solids. Its presence was the reason for the high turbidity occurrence in the water from the Weija Reservoir as demonstrated by Figure 5. The suspended solids in the Weija reservoir started declining after 2007, through to 2012, after which its concentration started increasing from 2013 to 2016. This indicated that there had been increased human activities around the water source within the last three years and this calls for maximum attention. The suspended solids end up in the water through run-offs from upstream forests where small scale gold mining, sand mining, and stone quarrying are done, and also from farm lands and waste water from anthropogenic activities. Ghrefat and Yusuf (2006) stated that activities such as small scale mining discharge waste water as well as run-off of silt and clay particles which result in high level of TSS in a nearby water body.

Total dissolved solids (TDS) comprise organic matter and inorganic salts (principally magnesium, calcium, sodium, chloride, bicarbonate and sulphates) that are dissolved in water. It was observed from Figure 14 that the level of total dissolved solids in the water throughout the 14-year period was very low, recording $196.8 \mathrm{mg} / \mathrm{L}$ as the highest average value for the study period. This level of total dissolved solids makes raw water from the Weija reservoir of good quality and thus palatable, as indicated by WHO (2011) that water is termed to be of good palatability if its total dissolved solids are less than $600 \mathrm{mg} / \mathrm{L}$. Thus, the taste and the overall health of the water will be good as the TDS values are far below $600 \mathrm{mg} / \mathrm{L}$. The total dissolved solids in drinking-water originate from urban runoff, sewage, industrial wastewater as well as natural sources (WHO, 2011). All the recordings from the years under study fell within the WHO guideline values $(500-1000 \mathrm{mg} / \mathrm{L})$.

\subsection{Total Hardness (Calcium and Magnesium)}

The amount of dissolved magnesium and calcium in water constitute to the total hardness level of water. The average levels of hardness in the water were within the acceptable limit of $500 \mathrm{mg} / \mathrm{L}$. It was also observed from Figure 15 that the level of hardness in the water was increasing from the last eight years $(2008-2016)$ and this calls for much attention as it is gradually getting close to $200 \mathrm{mg} / \mathrm{L}$. According to WHO (2011), water with hardness level above approximately $200 \mathrm{mg} / \mathrm{L}$ may lead to the deposition of scale in treatment works, tanks and distribution systems.

The pattern of occurrence of total hardness was influenced highly by the presence of calcium in the water. Inferences from Figure 15 and Figure 16 indicated that hardness was increasing with increasing calcium concentrations and vice versa. Though magnesium was present, it was in smaller quantities and also fell within WHO expected guideline value of $30 \mathrm{mg} / \mathrm{L}$. Such levels of magnesium are associated with increased vascular reactions, endothelial dysfunction and decreased insulin sensitivity as indicated by the WHO (2009). Calcium was the principal contributor to the hardness of water from the Weija reservoir. The calcium concentrations fell within the WHO guideline value of $50 \mathrm{mg} / \mathrm{L}$ except for the year 2007 which recorded $158.4 \mathrm{mg} / \mathrm{L}$. This was a major factor for the increase in the total hardness of the water for the last 8 years and signals a possibility of soap consumption during washing.

From the data, it was deduced that, the total hardness of the water in the Weija reservoir was highly influenced by the presence of calcium and magnesium ions which could occur naturally from weathering of sedimentary rocks, magnesium bearing minerals and calcium-bearing minerals of the river's basin.

\section{Conclusions}

This study can conclude on the basis of the results and findings from discussions that, most of the water quality parameters' average yearly recordings on water from the Weija Lake fell within the WHO standards during the 14-year period. Water from the Weija Lake can be termed to have been of high quality putting into consideration phosphorus, nitrate, ammonia, magnesium, calcium, total hardness, fluoride, iron, total dissolved solid, $\mathrm{pH}$ and sulphate since they fell within WHO guidelines; this effect gives a signal of resource sustainability by the population within the catchment. On the other hand, sustainability of the Weija reservoir by the people within the River Densu catchment was seen with little concern as the water can be termed to have been of less quality over the 14 years by considering parameters such as turbidity and colour since their recordings were often above WHO guidelines. Average yearly recordings on suspended solids were not encouraging since WHO advices that water for drinking should have no amount of suspended solids. Also, iron recordings signal a threat on the quality of the water since many of the yearly average recordings were not far from reaching the guideline of $0.3 \mathrm{mg} / \mathrm{L}$. On the whole, the study was able to analyze the trend in quality of raw water and establish some relationships among the water quality parameters over the 14-year period. 


\section{Recommendations}

Agricultural departments at the various district and municipal assemblies within the DRB are to either educate or encourage farmers on clean methods and technologies for farming so as to ensure that the water body maintains its low recordings of agricultural related parameters such as phosphate, nitrate and ammonia. In addition, sanitation departments at the various municipal and district assemblies are to ensure that proper measures are put in place to regulate and promote proper solid wastes disposal. This, when taken seriously, will result in the low recordings of turbidity, colur and total suspended solids in water from the Weija Lake. Also, activities such as small scale gold mining, sand mining and stone quarrying need to be regulated by stakeholders such as DRA, WRC, WHW and various MMDAs so as to ensure low recordings of dissolved solids and iron in the reservoir.

\section{References}

Anon. (2002) Population and Housing Census, Ghana Statistical Service, March 2002. Accra, 44-46.

Anon. (1997) Consultancy for the study of the ATMA development and Investment programme and of the Rehabilitation/Replacement of Kpong-Tema-Accra water pipeline, 4-21.

Ansa-Asare O. D. \& Asante K. A. (1998). A comparative study of the nutrient status of two reservoirs in southeast Ghana. Lakes and Reservoirs: Res. Mgmt 3: 205-217.

Asante, K. A., Quarcoopome, T. \& Amevenku, F. Y. K. (2005). Water quality of the Weija reservoir after 28 years of impoundment. West African Journal of Applied Ecology - Volume 13.

Bosque-Hamilton E. K., Nana-Amankwaa E. \& Karikari A. Y. (2004). A preliminary comparative limnological assessment of three coastal water supply reservoirs in Ghana. J. Ghana Sci. Ass. 6(1): 128-138.

Department for International Development (DFID). (1999). Assessment of environmental water quality standard. Final report. Water Engineering and Development Centre, Loughborough University, UK.

Fadiran, A. O, Dlamini, S. C., \& Mavuso, A. (2008). A comparative study of the phosphate levels in some surface and ground water bodies of Swaziland. Chemical Society of Ethiopia, 197-206.

Ghrefat, H. \& Yusuf, N. (2006). Assessing Mn, Fe, Cu, $\mathrm{Zn}$ and $\mathrm{Cu}$, pollution in bottom sediment of Wadi Al-Arab Dam. Chemspeheric, 6: 043.

Nukunya G. K. \& Boateng E. O. (1979). Weija Dam project: An evaluation/study of water utilisation behaviour and its related socio-economic impact. Report submitted to Canadian International Development Agency (CIDA).

Okeola, F.O., Kolawole, O.D., \& Ameen, O.M. (2010). Comparative study of physiochemical Parameters of water from a river and its surrounding Wells for possible interactive effect. Advances in Environmental Biology, 4(3) 336-340.

Piao, S, Ciais, P, Huang, Y, Shen, Z, Peng S, Li, J, Zhou, L, Liu, H, Ma, Y, Ding, Y, Friedlingstein, P, Liu, C, Tan, K, Yu, Y, Zhang, T., \& Fang, J. (2010). The impacts of climate change on water resources and agriculture in China. Nature. 467, 43-51.

Purtz, J. (2003). Chemical analysis of drinking water for India-Canada Environment www.docstoc.com/docs. Accessed on 2011 January 23rd.

Rosegrant, M.W. (2002). World water and food to 2025: dealing with scarcity. International Food Policy Research Institute: Washington, DC, USA.

Silberberg, M. S. (2000). Chemistry, the molecular nature of matter and change. 2nd ed. McGraw- Hill Companies, USA.

Stanistski, C. L, Eubanks, L. P, Middlecamp, C, H., \& Stratton, W, J. (2000). Chemistry in context. 3rd ed. McGraw-Hill, Boston.

United States Environmental Studies Board, (2003). Water quality criteria. National Academy of Science. U. S. A.

Vanden, J. P \& Bernacsek, G. M. (1990). Source Book for the Inland Fishery Resources of Africa, Vol 1. CIFA Technical Paper No 18/1. 240 pp.

Water Resources Commission (WRC), (2000). Water resources management problems, identification, analysis and prioritization study. CSIR-Water Research Institute, Accra, Ghana. 130-145.

World Health Organisation (1984). Guidelines for drinking water quality. World Health Organisation Standards. Geneva, Switzerland.

World Health Organization (2006). Guidelines for Drinking Water Quality. 3rd Ed. WHO press, Geneva, Switzerland.

World Health Organisation (2007). Chemical safety of drinking water: Assessing priorities for risk management. WHO, Geneva, Switzerland.

WHO (2009) Calcium and Magnesium in Drinking-water. World Health Organization, Geneva.

World Health Organization (2011). Guidelines for Drinking Water Quality. 3rd ed. WHO press, Geneva, Switzerland. 